\title{
ANALISIS KOMPETENSI PEDAGOGIK DOSEN PENGAMPU MATA KULIAH DALAM IMPLEMENTASI COMPUTER ASSISTED INSTRUCTION (CAI)
}

\author{
Vidya Pratiwi ${ }^{1)}$ \\ 1) Universitas Abdurachman Saleh Situbondo \\ pdeeyah@gmail.com
}

\begin{abstract}
ABSTRAK: Fokus penelitian ini meliputi kompetensi pedagogik dosen pengampu mata kuliah kiatannya dalam mengimplementasikan CAI di dalam proses belajar mengajar. Metode penelitian yang digunakan yakni deksrptif kualitatif. Analisis data yang digunakan melalui proses mencari dan menyusun secara sistematis data yang diperoleh dari hasil wawancara, catatan lapangan, dan dokumentasi dengan cara mengorganisasikan data ke dalam kategori, menjabarkan ke dalam unit-unit, melakukan sintesa, menyusun ke dalam pola, memilih mana yang penting dan yang akan dipelajari, dan membuat kesimpulan sehingga mudah dipahami oleh diri sendiri dan orang lain. Kompetensi pedagogik dosen pengampu mata kuliah dalam implementasi CAI yakni mendapatkan hasil penelitian yang menunjukan bahwa kompetensi pedagogik yang dimiliki oleh seorang dosen kaitannya dengan implementasi CAI dapat membuat mahasiswa menjadi meningkat dalam pengetahuan pembelajarannya terkait dengan perkembangan teknologi informasi pada saat ini.
\end{abstract}

Kata kunci : Kompetensi Pedagogik, Dosen, CAI

ABSTRACT: The focus of this study includes the pedagogical competence of lecturer lecturers in implementing CAI in the teaching and learning process. The research method used is qualitative descriptive. Analysis of the data used through the process of systematically searching and compiling data obtained from interviews, field notes, and documentation by organizing data into categories, breaking down into units, synthesizing, organizing into patterns, choosing which is important and what will be learned, and make conclusions so that they are easily understood by themselves and others. Pedagogical competence of lecturers supporting courses in CAI implementation that is getting research results that show that pedagogical competencies held by a lecturer in relation to CAI implementation can make students increase in their learning knowledge related to the development of information technology at this time.

Keywords: Pedagogical Competence, Lecturer, CAI

\section{PENDAHULUAN}

Proses pendidikan, kegiatan belajar merupakan kegiatan yang paling pokok. Berhasil tidaknya pencapaian tujuan pendidikan banyak bergantung pada bagaimana proses belajar yang dialami oleh pebelajar. Dapat kita ketahui bersama, bahwa belajar itu sangat kompleks, banyak siswa bahkan mahasiswa gagal mendapat hasil yang baik dalam pelajarannya karena mereka tidak mengetahui cara- cara belajar yang efektif. 
Salah satu pendukung dan peran serta atas berhasilnya seorang pebelajar yakni campur tangan seorang guru. Mengajar merupakan salah satu komponen dari kompetensikompetensi guru atau dosen. Setiap guru atau dosen harus menguasai materi perkuliahan serta terampil melaksanakan proses belajar mengajar demi tercapainya tujuan pembelajaran.

Menurut Suyanto (2013:80) Kompetensi pada dasarnya adalah deksripsi tentang apa yang dapat dilakukan seseorang dalam bekerja, serta bagaimana wujud dari pekerjaan tersebut yang dapat direalisasikan. Mengacu pada penjelasan diatas, kompetensi seorang dosen dalam melaksanakan keprofesiannya, baik berupa kegiatan, perilaku maupun hasil yang dapat ditunjukkan melalui kegiatan perkuliahan. Pada CAI perangkat lunak yang digunakan berfungsi membantu pengajar dalam proses pembelajaran, seperti sebagai multimedia, alat bantu dalam presentasi maupun demonstrasi dalam pelaksanaan pembelajaran. Dengan adanya konsep tersebut pencapaian tujuan pendidikan dan pembelajaran banyak bergantung pada bagaimana proses pembelajaran dikemas dan dirancang secara tepat dan professional. Pembelajaran harus didesain/ dirancang secara sistematik, sistematis dan berkesinambungan. Perpaduan dari kedua unsure tersebut melahirkan interaksi edukatif dengan memanfaatkan bahan, media dan sumber belajar sebagai mediumnya ((Rusman, 2012:3).

Observasi awal pada setiap dosen pengampu di prodi S1 PGSD Unars, masih banyak terdapat beberapa permasalah yang berkaitan dengan kompetensi pedagogik dosen yang di antaranya masih belum banyak yang memanfaatkan teknologi informasi dan komunikasi untuk kepentingan pembelajaran, baik kegiatan pembelajaran yang mendidik dan terkait dengan evaluasi pembelajaran dalam implementasi CAI.

Berdasarkan latar belakang diatas, maka peneliti ingin mengetahui dan mengkaji tentang "Analisis kompetensi pedagogik dosen pengampu mata kuliah dalam implementasi Computer Assisted Instruction (CAI) di prodi S1 PGSD Unars tahun ajaran 2018/2019".

\section{METODE PENELITIAN}

Pendekatan yang digunakan dalam penelitian ini adalah pendekatan kualitatif. Penelitian kualitatif adalah penelitian yang menghasilkan prosedur analisis yang tidak menggunakan prosedur analisis statistik atau cara kualifikasi lainnya. Penelitian kualitatif mempunyai dua tujuan utama, yaitu pertama, menggambarkan dan mengungkapkan (to describe and explore) dan kedua menggambarkan dan menjelaskan (to describe and explain). Kebanyakan penelitian kualitatif bersifat deskriptif dan explanatori. Beberapa penelitian memberikan deskripsi tenteng situasi yang kompleks, dan arah bagi peneliti selanjutnya.Bersifat deskriptif yakni penelitian kualitatif bersifat mendeskripsikan 'makna data' atau fenomena yang dapat ditangkap oleh peneliti, dengan menunjukkan bukti-buktinya. Penelitian kualitatif mengkaji perspektif partisipan dengan multi strategi, strategi-strategi yang bersifat interaktif, seperti observasi langsung, observasi partisipatif, 
wawancara mendalam, dokumen-dokumen, teknik-teknik pelengkap seperti foto, rekaman,dll.

\section{Sumber Data}

Setiap penelitian ilmiah memerlukan data dalam memecahkan masalah yang dihadapinya. Data harus diperoleh dari sumber data yang tetap agar data yang terkumpul relevan dengan masalah yang diteliti, sehingga tidak menimbulkan kekeliruan. Adapun data penelitian ini dapat dikelompokkan jadi 2 (dua),yaitu:

1. Data primer

Data primer adalah sumber data yang langsung memberikan data kepada pengumpul data. Sumber primer ini diperoleh dari observasi langsung terhadap para dosen pengampu mata kuliah. Tindakan orang-orang yang diamati atau kata-kata dari orang diwawancarai merupakan sumber data primer, maka peneliti juga akan melakukan wawancara langsung dengan dekan FKIP.

2. Data sekunder

Data sekunder adalah sunber yang tidak langsung memberikan data kepada pengumpul data. Biasanya berupa data dokumentasi, buku-buku maupun arsip-arsip resmi. Peneliti juga membutuhkan data sekunder berupa dokumen dari pihak fakultas terkait desain instruksional dosen, penguasaan dosen terhadap karakteristik peserta didik, penguasaan teori belajar dan prinsip pembelajaran, pengembangan kurikulum, kegiatan pembelajaran yang mendidik.

\section{Prosedur pengumpulan data}

a. Metode Observasi (pengamatan)

Pengamatan adalah alat pengumpulan data yang dilakukan dengan cara mengamati dan mencatat secara sistematik gejala-gejala yang diselidiki.Peneliti melakukan observasi atau pengamatan pada saatproses pembelajaran berlangsung.

b. Metode Wawancara

Teknik yang digunakan dalam penelitian ini adalah teknik wawancara semi terstruktur. Tujuan dari wawancara jenis ini adalah untuk menemukan permasalahan secara lebih terbuka, dimana fihak yang diajak wawancara diminta pendapat, dan ide-idenya. Wawancara dalam hal ini dimaksudkan untuk memperoleh informasi tentang hal-hal yang berkaitan dengan pokok penelitian ini yaitu tentang implementasi pembelajaran CAI ( Computer Assisted Instruction).

c. Metode dokumentasi

Dokumen merupakan catatan peristiwa yang sudah berlalu. Dokumen bisa berbentuk tulisan, gambar, atau karya-karya monumental dari seseorang.Dokumentasi dapat juga diartikan sebagai pengumpulan data dengan jalan mengambil keterangan secara tertulis dari tempat penelitian. Dokumentasi ini dapat berupa foto ketika proses pembelajaran tersebut berlangsung. 


\section{Analisis Data}

Analisis data adalah proses mencari dan menyusun secara sistematis data yang diperoleh dari hasil wawancara, catatan lapangan, dan dokumentasi dengan cara mengorganisasikan data ke dalam kategori, menjabarkan ke dalam unit-unit, melakukan sintesa, menyusun ke dalam pola, memilih mana yang penting dan yang akan dipelajari, dan membuat kesimpulan sehingga mudah dipahami oleh diri sendiri dan orang lain.

Proses analisis data dilakukan sebelum dan sepanjang proses penelitian berlangsung. Analisis data kualitatif terdiri dari lapangan tiga alur kegiatan yang terjadi secara bersamaan, yaitu:

a. Data reduction (Reduksi Data)

Data yang diperoleh dari lapangan jumlahnya cukup banyak, oleh karena itu perlu dicatat secara teliti dengan rinci, seperti yang telah dikemukakan bahwa semakin lama peneliti ke lapangan, maka jumlah data akan semakin banyak, kompleks, dan rumit. Untuk itu, perlu segera dilakukan analisis data melalui reduksi data. Mereduksi data berarti merangkum, memilih hal-hal yang pokok, memfokuskan pada hal-hal yang penting, di cari tema dan polanya. Dengan demikian data yang di reduksi akan memberikan gambaran yang lebih jelas dan mempermudah peneliti untuk melakukan data selanjutnya dan mencarinya bila diperlukan.Pada tahap ini peneliti merangkum dan memilih data yang didapatkan dari penelitian terkait implementasi pembelajaran CAI ( Computer Assisted Instruction) pada kemampuan pedagogic dosen pengampu mata kuliah, sehingga ketika masuk di lapangan peneliti akan mudah dalam melakukan penelitian karena sudah mempunyai bahan yang akan diteliti.

b. Data Display (Penyajian Data)

Data yang telah selesai di reduksi, maka langkah selanjutnya adalah mendisplaykan data tersebut.Dalam penelitian kualitatif penyajian databiasa dilakukan dalam bentuk uraian singkat, bagan, hubungan antar kategori. Dengan mendisplaykan data, maka akan memudahkan untuk memahami apa yang terjadi, merencanakan kerja selanjutnya berdasarkan apa yang telah difahami.Dalam hal ini peneliti menarasikan temuan tentang implementasi pembelajaran CAI ( Computer Assisted Instruction).

c. Kesimpulan dan verifikasi

Langkah ketiga dalam analisis data kualitatif menurut Miles and Huberman adalah penarikan kesimpulan dan verifikasi. Kesimpulan masih bersifat sementara dan akan berubah bila tidak ditemukan bukti-bukti kuat yang mendukung pada tahap pengumpulan data berikutnya. Dengan demikian, kesimpulan di dalam penelitian kualitatif mungkin dapat menyelesaikan rumusan masalah yang dirumuskan peneliti sejak awal, akan tetapi mungkin juga tidak dikarenakan masalah dan rumusan masalah di dalam penelitian kualitatif bersifat sementara dan akan berkembang ketika berada di lapangan. Penelitian kualitatif di lapangan diharapkan mampu menemukan sebuah penemuan baru yang sebelumnya belum pernah ada. Temuan tersebut dapat berupa deskripsi atau gambaran suatu objek yang sebelumnya masih 
bersifat remang-remang atau gelap. Peneliti memberikan kesimpulan bahwa implementasi pembelajaran CAI (Computer Assisted Instruction).

\subsection{Uji keabsahan data}

a. Perpanjangan pengamatan

Dengan perpanjangan pengamatan ini, peneliti mengecek kembali apakah data yang telah diberikan selama ini merupakan data yang sudah benar atau tidak. Perpanjangan pengamatan ini peneliti lakukan dengan cara wawancara terhadap nara sumber lain.

b. Meningkatkan ketekunan

Meningkatkan ketekunan berarti melakukan pengamatan secara lebih cermat dan berkesinambungan. Dengan cara tersebut, maka kepastian data dan urutan peristiwa akan dapat diyakini secara pasti dan sistematis.Meningkatkan ketekunan ini dilakukan dengan cara peneliti membaca seluruh catatan hasil penelitian secara cermat, sehingga dapat diketahui kesalahan dankekurangan.

c. Triangulasi

Triangulasi dalam pengujian kredibilitas ini diartikan sebagai pengecekan data dari berbagai sumber dengan berbagai cara, dan berbagai waktu.Dengan demikian, analisis ini menggunakan tiga langkah, yaitu meliputi:

1) Triangulasi sumber

Triangulasi sumber untuk menguji kredibilitas data dilakukan dengan cara mengecek data yang telah diperoleh melalui beberapa sumber. Peneliti melakukan wawancara dari berbagai nara sumber, dan diharapkan terdapat sinkronisasi jawaban yang menunjukkan kebenaran implementasi pembelajaran CAI ( Computer Assisted Instruction)

2) Triangulasi tehnik

Triangulasi tehnik untuk menguji kredibilitas data, dilakukan dengan cara mengecek data kepada sumber yang sama dengan tehnik berbeda, misalnya data diperoleh dari wawancara kemudian dicek dengan observasi dan dokumentasi. Dalam penelitian ini teknik yang digabungkan adalah teknik wawancara, observasi, dan dokumentasi dengan sumberdata.

3) Triangulasi waktu

Waktu juga mempengaruhi kredibilitas. Data yang akan dikumpulkan dengan wawancara dipagi hari, ketika narasumber masih segar, belum banyak masalah, maka akan memberikan data dengan lebih valid sehingga lebih kredibel. Hal ini dimaksudkan untuk melihat apakah yang dikatakan oleh narasumber dari satu sumber itu benar-benar dari realitas atau sesuatu yang dibuat-buat, atau untuk mempertajam informasi yang telah didapatkan dalam penelitian implementasi pembelajaran CAI ( Computer Assisted Instruction) 
d. Member check

Member check adalah proses pengecekan data yang diperoleh peneliti kepada pemberi data. Tujuan dari member check ini adalah untuk mengetahui seberapa jauh yang diperoleh sesuai dengan apa yang diberikan oleh pemberi data. Dengan adanya member check, peneliti akan menguji kemungkinan dugaan-dugaan yang berbeda dan mengembangkan pengujian-pengujian untuk mengecek analisis, dengan mengaplikasikannya pada data, serta dengan mengajukan pertanyaan-pertanyaan tentangdata.

\section{HASIL DAN PEMBAHASAN}

Kompetensi Pedagogik pada dasarnya adalah kemampuan guru dalam mengelola pembelajaran peserta didik. Kompetensi Pedagogik merupakan kompetensi khas, yang akan membedakan guru dengan profesi lainnya dan akan menentukan tingkat keberhasilan proses dan hasil pembelajaran peserta didiknya. Kompetensi ini tidak diperoleh secara tiba-tiba tetapi melalui upaya belajar secara terus menerus dan sistematis, baik pada masa pra jabatan (pendidikan calon guru) maupun selama dalam jabatan, yang didukung oleh bakat, minat dan potensi keguruan lainnya dari masingmasing individu yang bersangkutan.

Pada penelitian ini ada 4 kompetensi yang dibahas yaitu : 1) Menguasai karakteristik peserta didik dari aspek fisik, moral, spiritual, sosial, kultural, emosional, dan intelektual; 2) Menguasai teori belajar dan prinsip-prinsip pembelajaran yang mendidik dalam implementasinya dengan CAI; 3) Mengembangkan kurikulum yang terkait dengan mata kuliah yang diampu kaitannya dengan CAI; 4) Kegiatan pembelajaran yang mendidik kaitannya dengan implementasi CAI. Pada Indikator pertama, semua dosen yang menjadi subyek penelitian sudah dapat menguasai karakteristik peserta didiknya dari aspek fisik, moral, kultural, emosional dan intelektual. Dengan hal ini sangat penting bagi guru untuk mengetahui karakteristik peserta didiknya agar lebih mudah dalam menyampaikan materi pelajaran jika sudah mengetahui karakteristi peserta didik.

Sesuai penjelasan diatas, bahwa mengetahui karakteristik peserta didik memang sangat penting bagi seorang dosen dalam menentukan pembelajarannya. Pada Indikator kedua, dosen sudah menguasai terhadap teori belajar dan prinsip-prinsip pembelajaran. Dosen dalam menguasai teori belajar yaitu dengan menggunakan pendekatan maupun model-model pembelajaran pada setiap proses pembelajaran secara kreatif dan mengimplementasikan CAI dengan baik.

Menurut penjelasan diatas, bahwa penguasaan dosen terhadap teori belajar dan prinsip-prinsip pembelajaran sudah menggunakan pendekatan CAI pada setiap proses pembelajarannya Serta implementasi CAI dapat merubah cara pemberian informasi secara utuh dari dosen ke mahasiswa. 
Pada indikator ketiga, dosen sudah dapat mengembangkan kurikulum dengan mengikuti pelatihan dan juga dosen mengembangkan kurikulum dengan mengembangkan perangkat perkuliahan yang lebih efektif menyesuaikan dengan karakteristik peserta didik namun tidak keluar dari konteks pembelajaran yang seluruh kegiatannya tersebut dikaitkan dengan CAI. Penjelasan untuk indikator ketiga yakni dosen pengampu mata kuliah sudah mampu mengembangkan kurikulum berbasis teknologi informasi dengan baik. Pada indikator keempat, dosen sudah dapat memberikan pembelajaran yang mengimplementasikan dengan CAI serta sudah memanfaatkan adanya teknologi informasi dan komunikasi. Implementasi CAI dalam kegiatan pembelajaran sudah tertata dengan baik, dan seluruh dosen pengampu mata kuliah memanfaatkan adanya teknologi informasi dan komunikasi.

\section{Upaya Dosen Untuk Meningkatkan Kompetensi Pedagogik Kaitannya Dengan Implementasi CAI}

Motivasi dari dalam diri dosen untuk meningkatkan kompetensi pedagogiknya dalam kaitannya dengan implementasi CAI akan lebih kuat. Karena motivasi intern tumbuh dari kesadaran akan kebutuhan seseorang untuk mengembangkan diri. Peningkatan komepetensi yang bisa dilakukan oleh guru secara pribadi antara lain :

1. Menambah pengetahuan tentang perkembangan teknologi informasi dan komunikasi

2. Perkembangan teknologi sekarang ini telah banyak menunjukkan kemajuan yang luar biasa. Banyak hal dari sektor kehidupan yang telah menggunakan keberadaan dari teknologi itu sendiri. Kehadirannya telah memberikan dampak yang cukup besar terhadap kehidupan umat manusia dalam berbagai aspek dan dimensi. Demikian halnya dengan teknologi komunikasi yang merupakan peralatan perangkat keras dalam struktur organisasi yang mengandung nilai sosial yang memungkinkan individu untuk mengumpulkan, memproses dan saling tukar informasi (menurut Rogers,1986). Keadaan yang demikian, dimana sebuah teknologi mampu merubah sesuatu yang belum tentu dapat dilakukan menjadi sebuah kenyataan. Misalnya, kalau dahulu orang tidak dapat berbicara dengan orang lain yang berada di suatu tempat yang berjarak jauh, maka setelah adanya telepon orang dapat berbicara tanpa batas dan jarak waktu.

3. Menambah pengetahuan tentang penggunaan media pembelajaran agar semakin bervariasi

Bruner (1966) mengungkapkan ada tiga tingkatan utama modus belajar, seperti: enactive (pengalaman langsung), iconic (pengalaman piktorial atau gambar), dan symbolic (pengalaman abstrak). Pemerolehan pengetahuan dan keterampilan serta perubahan sikap dan perilaku dapat terjadi karena adanya interaksi antara pengalaman baru dengan pengalaman yang telah dialami sebelumnya melalui proses 
belajar. Sebagai ilustrasi misalnya, belajar untuk memahami apa dan bagaimana mencangkok. Dalam tingkatan pengalaman langsung, untuk memperoleh pemahaman pebelajar secara langsung mengerjakan atau membuat cangkokan. Pada tingkatan kedua, iconic, pemahaman tentang mencangkok dipelajari melalui gambar, foto, film atau rekaman video. Selanjutnya pada tingkatan pengalaman abstrak, siswa memahaminya lewat membaca atau mendengar dan mencocokkannya dengan pengalaman melihat orang mencangkok atau dengan pengalamannya sendiri.

4. Mengedepankan inovasi baru

Daya kreativitas dan inovasi secara alamiah telah dimiliki oleh setiap orang. Namun tumbuh danberkembangnya pada setiap orang ini akan berbeda tergantung dari kesempatan masing-masing untukmengembangkannya. Pengembangan atau tumbuhnya dengan subur kreativitas dan inovasi pada setiaporang atau sehubungan dengan pekerjaan guru adalah dengan adanya latihan yang berkesinambungan.Latihan ini harus dibarengi pula dengan penanaman sikap dan nilai yang luhur, yaitu sikap seorang ilmuwan. Inovasi pembelajaran merupakan sesuatu yang penting dan mesti dilakukan oleh dosen. Dengan adanya inovasi pembelajaran maka kita sebagai pengajar sebaiknya dapat belajar menciptakan suasana belajar yang menyenangkan, menggairahkan, dinamis, penuh semangat, dan penuhtantangan. Suasana pembelajaran seperti itu dapat mempermudah peserta didik dalam memperoleh ilmu dan guru juga dapat menanamkan nilai-nilai luhur yang hakiki pada peserta didik untuk menuju tercapainya tujuan pembelajaran.

Mendidik tidak hanya sekedar mentransfer ilmu kepada peserta didik, tetapi juga membuka pola pikir mereka bahwa ilmu yang mereka pelajari memiliki kebermaknaan untuk hidup mereka sehingga dari ilmutersebut, mampu merubah sikap, pengetahuan, dan keterampilan mereka menjadi lebih baik. Penguasaan terhadap materi yang dikelola dan ditampilkan secara profesioal, dari hati dan tanpapaksaan, logis, dan menyenangkan, serta dipadukan dengan pendekatan personal-emosional terhadappeserta didik akan menjadikan proses pembelajaran yang ingin dicapai terwujud. Selain itu, pembelajaran juga harus dibuat bervariasi dengan menciptakan suatu metode pembelajaran yang baru atau dengan katalain inovasi.

Inovasi pembelajaran merupakan sesuatu yang penting dan harus dimiliki atau dilakukan oleh guru. Hal ini disebabkan karena pembelajaran akan lebih hidup dan bermakna. Kemauan guru untuk mencobamenemukan, menggali dan mencari berbagai terobosan, pendekatan, metode dan strategi pembelajaran merupakan salah satu penunjang akan munculnya berbagai inovasi-inovasi baru.

Tanpa didukung kemauan dari guru untuk selalu berinovasi dalam pembelajarannya, makapembelajaran akan menjenuhkan bagi mahsiswa. Di samping itu, dosen tidak dapat mengembangkan potensi yang dimilikinya secara optimal. Mengingat sangat pentingnya inovasi, maka inovasi menjadi sesuatu yang harus dicoba untuk 
dilakukan oleh setiap dosen. Oleh karena itu, seorang dosen harus selalu melakukan inovasi dalam pembelajaran. Langkah yang dapat dilakukan yakni perbaikan cara mengajar dosen dengan menggunakan metode baru yang inovatif serta dapat menafaatkan media pembelajaran dengan inovasi terbaru.

\section{KESIMPULAN DAN SARAN}

\section{Kesimpulan}

Pada akhir penelitian ini, dapat disimpulkan bahwa kompetensi pedagogic yang dimilik oleh dosen kaitannya dengan implementasi CAI baik dari penguasaan karakterisitik, penguasaan teori belajar, pengembangan kurikulum dan kegiatan pembelajaran yang menarik dalam kaitannya dengan implementasi CAI.

Berdasarkan penjelasan hasil penelitian yang dibahas pada bab sebelumnya, dapat ditarik kesimpulan mengenai kompetensi pedagogik dosen pengampu mata kuliah dalam implementasi CAI yakni mendapatkan hasil penelitian yang menunjukan bahwa kompetensi pedagogik yang dimiliki oleh seorang dosen kaitannya dengan implementasi CAI dapat membuat mahasiswa menjadi meningkat dalam pengetahuan pembelajarannya terkait dengan perkembangan teknologi informasi pada saat ini.

\section{Saran}

Sebagai akhir dari penulisan hasil penelitian ini, maka penulis akan memberikan saran-saran sebagai berikut :

1. Bagi siswa, sebagai seorang anak yang baik maka hendaknya siswa jangan menyianyiakan pehatian yang telah diberikan oleh orang tua dan lebih meningkatkan efektifitas membacanya.

2. Bagi orang tua, hendaknya memberikan dukungan kepada putra putrinya dalam belajar agar mencapai hasil belajar yang baik.

3. Bagi penelitian lain, dapat dijadikan sebagai masukan untuk mengadakan penelitian lebih lanjut.

\section{DAFTAR RUJUKAN}

Arikunto, Suharsimi.1998. Prosedur Penelitian. Yogyakarta: Rineka cipta.

Gumanti, Tatang ary, dkk. 2016. Metode penelitian pendidikan. Jakarta : Mitra wacana media

Hamzah dan Lamatenggo, Nina. 2011. Teknologi Komunikasi dan Informasi Pembelajaran. Jakarta : Bumi Aksara

Mahdiyah. 2016. Statistik pendidikan. Bandung : Rosdakarya

Rusman. 2013. Belajar dan Pembelajaran berbasis computer. Bandung : Alfabeta. 
Slameto. 2015. Belajar dan factor-faktor yang mempengaruhi. Jakarta : PT. Asdi Mahasatya.

Sugiyono. 2013. Metode Penelitian kuantitatif dan kualitatif dan R\&D. Bandung : Alfabeta.

Suyanto dan Jihad, Asep. 2013. Menjadi Guru Profesional. Jakarta : Erlangga. 